\section{THE INFLUENCE OF ISCHEMIC PRECONDITIONING ON NEUROMUSCULAR PERFORMANCE}

\author{
INFLUÊNCIA DO PRÉ-CONDICIONAMENTO ISQUÊMICO NO DESEMPENHO NEUROMUSCULAR \\ INFLUENCIA DEL PREACONDICIONAMIENTO ISQUÉMICO EN EL DESEMPEÑO NEUROMUSCULAR
}

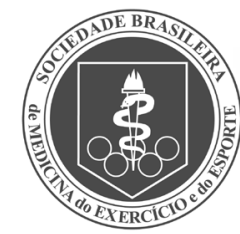

Original Article ARtIGo Original Artículo Original
Vinícius José de Santana' (ID (Physical Education Professional) Carlos Eduardo de Oliveira Deângelo' (1D (Physical Education Professional) Vera Maria Cury Salemi ${ }^{2}$ (DD (Physician)

Douglas Pinheiro Miranda ${ }^{1,2}$ (DD (Physical Education Professional)

1. Physical Evaluation and Exercise Physiology Laboratory (LAFFEX), Physical Education Course of the Centro Universitário da Fundação Educacional de Barretos, Barretos, SP, Brazil.

2. Instituto do Coração (Incor) of the Hospital das Clínicas da Faculdade de Medicina of the Universidade de São Paulo, São Paulo, SP, Brazil.

\section{Correspondence:}

Douglas Pinheiro Miranda. Coordenação de Pós-graduação, Instituto do Coração. Av. Dr. Enéas Carvalho Aguiar, 44, Cerqueira César, São Paulo, SP, Brasil. 05403-000.

douglas@pinheiromiranda.com douglasmiranda@alumni.usp.br

\section{ABSTRACT}

Introduction: Ischemic preconditioning (IPC) has been described in the literature as a resource capable of improving physical performance. Objective: The purpose of this randomized double-blind study was to evaluate the influence of IPC on the neuromuscular performance of trained individuals. Methods: Twenty-four (24) resistance training participants ( 6 of them women) with a mean age of $25.8 \pm 4.6$ years were selected and divided into two groups: the upper limb group (ULG) composed of 12 individuals ( 4 women) and the lower limb group (LLG) composed of 12 individuals ( 2 women). The maximum repetitions test was applied in the bench press for the ULG and in the $45^{\circ}$ leg press for the LLG, with $50 \%$ of the one-repetition maximum under control, placebo and IPC conditions, at a random interval of 72 hours between tests. The IPC was applied four hours before the tests by means of an analog sphygmomanometer cuff inflated to $220 \mathrm{mmHg}$ on the arm for the ULG and on the thigh for LLG, with three cycles of five minutes each of ischemia and reperfusion, alternating between the right and left sides. For the placebo, the cuff was inflated to $40 \mathrm{mmHg}$ without causing ischemia. The significance level for the Wilcoxon test was $p<0.017$, due to the Bonferroni correction. The effect size (ES) was also analyzed. Results: With IPC, the ULG performed $34.8 \pm 4.8$ repetitions, representing an improvement of $11.29 \%$ (IPC vs. control, ES $=0.68$ and $p=$ 0.002 ) and the LLG performed $40.5 \pm 15.7$ repetitions, representing an improvement of $37.47 \%$ (IPC vs. control, ES $=0.84$ and $p=0.002)$. No significant improvements were observed for the placebo in either group. Conclusion: Our data showed that IPC positively influenced neuromuscular performance of both the upper and lower limbs. Level of evidence Il; Therapeutic studies investigating the results of treatment (Prospectived comparative studye).

Keywords: Resistance training; Muscle strength; Ischemia; Tensile strength.

\section{RESUMO}

Introdução: O pré-condicionamento isquêmico (PCI) tem sido descrito na literatura como um recurso capaz de melhorar o desempenho físico. Objetivo: O objetivo deste estudo randomizado duplo cego foi avaliar a influência do PCI no desempenho neuromuscular de indivíduos treinados. Métodos: Foram selecionados 24 individuos (6 mulheres) com média de idade de 25,8 4,6 anos, praticantes de treinamento resistido, divididos em dois grupos, sendo um grupo de membros superiores (GMS), composto por 12 individuos (4 mulheres) e grupo de membros inferiores (GMI), composto por 12 indivíduos (2 mulheres). O teste de repetições máximas foi aplicado no exercício de supino para o GMS e no leg press $45^{\circ}$ para o GMI com 50\% de uma repetição máxima, nas condições de controle, placebo e PCI, de forma aleatória com intervalo de 72 horas entre os testes. O PCI foi aplicado quatro horas antes dos testes por meio de um manguito de esfigmomanômetro analógico inflado a $220 \mathrm{mmHg}$ no braço para o GMS e na coxa para o GMI, sendo três ciclos de cinco minutos de isquemia e cinco minutos de reperfusão, alternando os lados direito e esquerdo. Para o placebo, o manguito ficou em $40 \mathrm{mmHg}$, sem provocar isquemia. O nível de significância do teste de Wilcoxon foi dep $<0,017$, devido à correção de Bonferroni. Otamanho do efeito (TE) também foi analisado. Resultados: Com o PCl, o GMS realizou 34,8 $\pm 4,8$ repetições, representando melhora de 11,29\% ( $P C l$ vs. controle, $T E=0,68$ e $p=0,002$ ) e o GMl realizou 40,5 $\pm 15,7$ repetições, representando melhora de 37,47\% (PCl vs. controle, TE =0,84 e $p=0,002$ ). Com o placebo, ambos os grupos não apresentaram melhora. Conclusão: Nossos dados mostraram que o PCl influenciou positivamente o desempenho neuromuscular tanto de membros superiores quanto inferiores. Nível de evidência ll; Estudos terapêuticos-Investigação dos resultados do tratamento (Estudo prospectivo comparativo).

Descritores: Treinamento de resistência; Força muscular; Isquemia; Resistência à tração.

\section{RESUMEN}

Introducción: El preacondicionamiento isquémico (PCI) ha sido descrito en la literatura como un recurso capaz de mejorar el desempeño físico. Objetivo: El objetivo de este estudio aleatorio doble ciego fue evaluar la influencia del PCI en el desempeño neuromuscular de individuos entrenados. Métodos: Fueron seleccionados 24 individuos (6 mujeres) con promedio de edad de 25,8 4 4,6 años, practicantes de entrenamiento resistido, divididos en dos grupos, siendo un grupo de miembros superiores (GMS) compuesto por 12 individuos (4 mujeres) y grupo de miembros inferiores (GMI) compuesto por 12 individuos (2 mujeres). El test de repeticiones máximas fue aplicado en el ejercicio de supino para el GMSy en el leg press $45^{\circ}$ para el GMI con 50\% de una repetición máxima, en las condiciones de control, placebo y PCI, 
de forma aleatoria con intervalo de 72 horas entre los tests. EI PCI fue aplicado cuatro horas antes de los tests mediante un manguito de esfigmomanómetro analógico inflado a $220 \mathrm{mmHg}$ en el brazo para el GMS y en el muslo para el GMI, siendo tres ciclos de cinco minutos de isquemia y cinco minutos de reperfusión, alternando los lados derecho e izquierdo. Para el placebo, el manguito quedó en $40 \mathrm{mmHg}$, sin provocar isquemia. El nivel de significancia del test de Wilcoxon fue $p<0,017$, debido a la corrección de Bonferroni. El tamaño del efecto (TE) también fue analizado. Resultados: Con el PCl, el GMS realizó $34,8 \pm 4,8$ repeticiones, representando mejora de 11,29\% ( $P C l$ vs control, TE $=0,68$ y $p=0,002$ ) y el GMI realizó 40,5 $\pm 15,7$ repeticiones, representando mejora de 37,47\% ( $P C$ l vs control, $T E=0,84$ y $p=0,002$ ). Con el placebo, ambos grupos no mostraron mejora. Conclusión: Nuestros datos mostraron que el PCl influenció positivamente el desempeño neuromuscular tanto de miembros superiores como inferiores. Nivel de evidencia ll; Estudios terapéuticos: investigación de los resultados del tratamiento (estudio comparativo prospectivo).

Descriptores: Entrenamiento de resistencia; Fuerza muscular; Isquemia; Resistencia a la tracción.

\section{INTRODUCTION}

Ischemic preconditioning (IPC) has been described in the literature as a resource capable of improving physical performance, speculating that the physiological mechanisms responsible for such improvement are associated with the fact that IPC provides a decrease in ischemic stress, thus reducing muscle damage during high-intensity exercises through peripheral vasodilation accompanied by greater local blood flow and tissue oxygenation, in addition to an ATP-sparing effect due to more efficient muscle contraction, improved mitochondrial efficiency, and a reduction in signs of fatigue..$^{1-3}$

Characterized by brief periods of ischemia followed by blood reperfusion applied to one or more body segments, mainly the arm or thigh, IPC was initially described in the literature as a technique for preventing myocardial injuries. ${ }^{4,5,6}$ Two decades ago, IPC began to be investigated as a strategy to improve sports performance. 7 Previous studies showed that IPC promoted an increase in oxygen consumption and strength production after a maximum incremental test in trained cyclists. ${ }^{8}$ The positive effects of IPC on the performance of highly-trained swimmers, ${ }^{9}$ as well as in runners, ${ }^{10-11}$ were also observed.

On the other hand, there are data in the literature showing that IPC has no significant influence on running performance. ${ }^{12,13,14}$ Interestingly, after amateur cyclists performed Wingate test, the IPC had a detrimental effect on performance, decreasing the total anaerobic power of the individuals, ${ }^{15}$ and in swimming, 2 and 24 hours after administration of IPC, no changes in performance were observed in either the 100 or 200 meter swims. ${ }^{16}$

Thus, It is noted that the real effect of IPC on performance is controversial in the literature, perhaps due to methodological differences among the studies, including differences in the sports modalities, protocols used, the ways of performing the exercises, exercise durations, and the time between the IPC and the effort, making it difficult to provide guidelines about the use of IPC in the sports environment. ${ }^{3}$ Therefore, there is a persistent gap in the literature, especially in terms of the influence of IPC in strength exercises or in sports where physical capacity is predominant, given that most studies available in the literature focus their efforts on analyzing performance in dynamic exercises.

Recent literature data have shown a positive influence of IPC on strength resistance in knee extension, but the results are not yet consolidated ${ }^{17}$ and further research is needed in this regard. Thus, the objective of this study was to investigate the influence of IPC on the neuromuscular performance of the upper and lower limbs of trained individuals.

\section{METHODS}

\section{Sample}

This was a double-blind, randomized study in which 24 individuals ( 6 women) between 18 and 34 years of age (25.8 \pm 4.6$)$ participated, all of them having practiced resistance training regularly for the past $4.3 \pm 2.9$ years. They all signed the informed consent form. This study was approved by the Institutional Review Board of the Centro Universitário da Fundação Educacional de Barretos as number 60434016.4.0000.5433.

The inclusion criteria were (1) to have been practicing weight training for a period longer than 2 years without interruption and (2) to have been performing the bench press and $45^{\circ}$ leg press exercises systematically during this period. The exclusion criteria were (1) any metabolic or cardiac disease, (2) use of anabolic steroids, (3) hormone replacement therapy, (4) use of medications and (5) joint/muscle pain or injuries. The individuals were instructed not to initiate or suspend any type of dietary supplementation or to make any significant dietary changes during the study. In addition, the volunteers were to abstain from any type of stimulant, alcoholic beverage and vigorous exercise for at least 48 hours prior to the tests. Table 1 presents a characterization of the study participants.

\section{Experimental Sequence}

Prior to the study procedures, on the first visit to the laboratory, in addition to anamnesis and anthropometric evaluations, all the participants were familiarized with the procedures and the study equipment (IPC intervention, strength test and localized muscle resistance test). Next, they were randomly divided into two groups, one for the upper limbs (ULG) with 12 participants (4 women) who had only the upper limbs occluded and performed bench press tests, and the other for the lower limbs (LLG) also with 12 participants ( 2 women) who had only the lower limbs occluded and performed $45^{\circ} \mathrm{leg}$ press exercises for the test. Subsequently each individual returned to the laboratory four more times, with a minimum interval of 72 hours and no more than five days between visits, one to perform the one-repetition maximum (1RM) test and the others for application of the one-repetition test under three different conditions (control, placebo and IPC) randomly. The placebo and IPC procedures were conducted four hours before the tests. The researcher who administered the IPC and the maximum repetition test evaluator were different people, the evaluator not knowing which of the three interventions the individual had undergone hours before. The participants did not know that one of the interventions was a placebo, in order to guarantee a double-blind study. The tests were conducted at the same time of day for each individual, ensuring similar environmental conditions in all assessments (Figure 1).

Table 1. Characterization of the study participants presented as means and standard deviation.

\begin{tabular}{c|c|c|c}
\hline & ULG $(\mathbf{n}=\mathbf{1 2})$ & LLG $(\mathbf{n}=\mathbf{1 2})$ & Total $(\mathbf{n}=\mathbf{2 4})$ \\
\hline Age (years) & $25.5 \pm 3.3$ & $26.2 \pm 4.8$ & $25.9 \pm 4.1$ \\
\hline Height $(\mathrm{cm})$ & $172.7 \pm 11.0$ & $174.2 \pm 7.1$ & $173.5 \pm 9.1$ \\
\hline Weight $(\mathrm{kg})$ & $76.5 \pm 16.0$ & $76.6 \pm 10.0$ & $76.6 \pm 13.1$ \\
\hline Training time (years) & $4.0 \pm 2.5$ & $4.6 \pm 3.3$ & $4.3 \pm 2.9$ \\
\hline
\end{tabular}




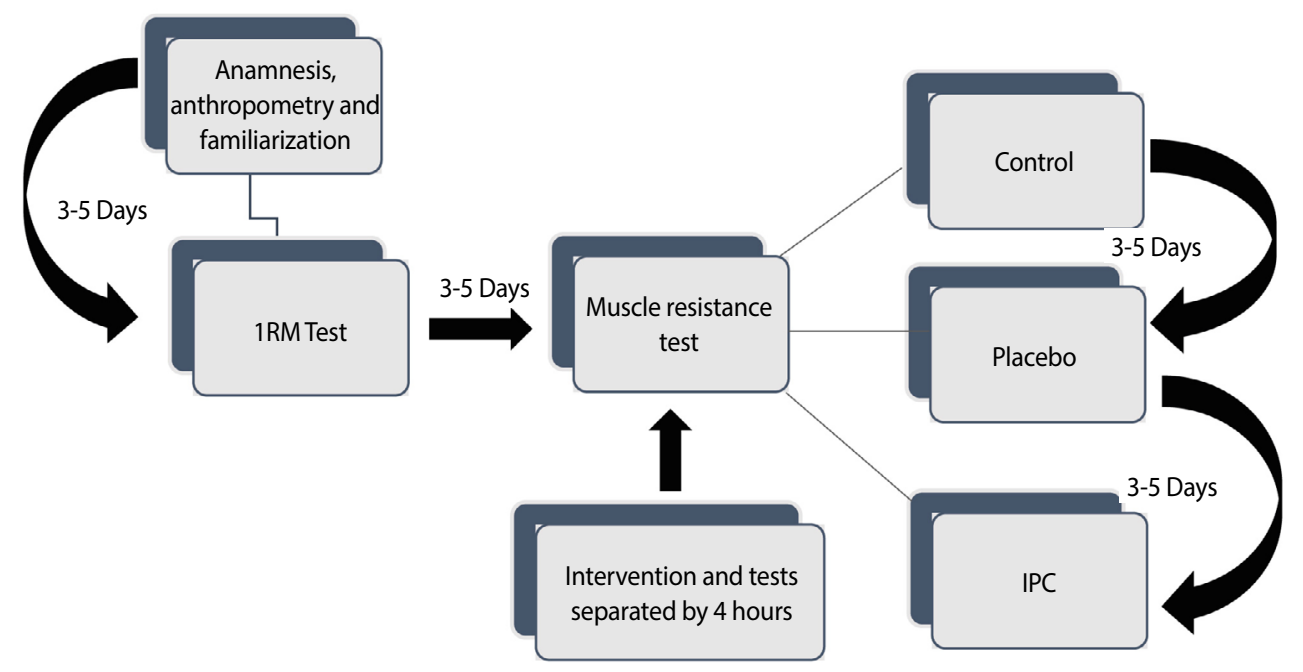

Figure 1. Experimental study design.

\section{Evaluation of Neuromuscular Capacity}

After all the participants were properly familiarized with the study procedure, the one-repetition maximum (1RM) test was administered, with the execution of two warmup series of 20 repetitions separated by one minute with submaximal load. Three minutes after the warmup, a maximum of four attempts were performed to determine the 1RM load, according to previous studies. ${ }^{18}$ For the $U L G$, the bench press was performed for the test and for the LLG, the $45^{\circ}$ leg press was used.

Four hours after the IPC or placebo interventions, respecting the same time frame for the control, the maximum repetition test was performed (until concentric failure) with a load corresponding to 50\% of the 1RM in the same exercises. Three minutes before the test, a series of 15 repetitions at $25 \%$ of the 1 RM was performed as a warm-up. The movement speed was $\sim 1$ second in each phase (concentric/eccentric), with a standardized range of motion of $90^{\circ}$ in all repetitions both for the elbows in the ULG and the knees in the LLG.

\section{Ischemic preconditioning}

The IPC was conducted with the participants in dorsal decubitus. Ischemia was caused by vascular occlusion using the cuff of an analog scale sphygmomanometer, model Premium ML 040 (BIC - Itupeva, SP, Brazil), inflated to $220 \mathrm{mmHg}$, in three five-minute series of ischemia interspersed with five minutes of reperfusion in each limb alternating between the left and right limbs, totaling 30 minutes of intervention.,3,10,18-20\{Kooijman, $2008 \# 1\}$ The protocol used for the placebo intervention was identical with the exception that the cuff was only inflated to 40 $\mathrm{mmHg}$ without causing any blood flow blockage, that is, without causing ischemia." During the procedure, auscultation of the radial arteries in the ULG and the posterior tibial artery in the LLG was performed using a Littmann model Classic II SE stethoscope (3M company - Maplewood, $\mathrm{MN}, \mathrm{USA}$ ) to verify the presence or absence of vascular occlusion in the IPC and placebo procedures, respectively.

\section{Statistical analysis}

The Shapiro-Wilk test was used to verify the normality of distribution of the quantitative variables. For the comparisons between the three moments, the placebo, control and IPC, the Friedman non-parametric test was used with a significance level of $p<0.05$. To discriminate the differences the Wilcoxon test was used, consequently applying the Bonferroni correction. The level of significance for this test was $p<0.017$.

The effect size (ES) was classified as trivial $(<0.35)$, small $(0.35$ to 0.80$)$, moderate ( 0.80 to 1.50 ) and large (>1.5), based on the specific guidelines for strength-trained individuals. ${ }^{19}$ The data were analyzed by means of the SPSS, version 20 program (IBM - Armonk, NY, USA).

\section{RESULTS}

The ULG individuals performed $31.4 \pm 5.1$ repetitions in the control moment. In the placebo intervention, this number did not change, remaining at $31.4 \pm 5.0$ repetitions, while in the IPC moment they performed $34.8 \pm 4.8$ repetitions, showing increases of $11.29 \%$ and $11.20 \%$ in relation to the control and placebo moments, respectively. The ES was considered trivial between the control and the placebo $(E S=0.00)$, and small between the IPC and the control $(E S=0.68)$ and between the IPC and the placebo ( $E S=0.69)$.

The LLG individuals performed $28.9 \pm 6.0$ repetitions in the control moment, $33.5 \pm 10.4$ repetitions in the placebo moment and $40.5 \pm 15.7$ repetitions in the IPC moment, showing increases of $37.47 \%$ and $22.05 \%$ in relation to the control and placebo moments, respectively. The ES was considered small between the control and the placebo $(E S=0.51)$ and the IPC and the placebo ( $E S=0.50)$ and moderate between the IPC and the control $(E S=0.84)$.

The Friedman test showed a difference in the comparison between the control, placebo and IPC for both the ULG and the LLG $(p<0.001)$. Table 2 presents the results of the statistical tests conducted to discriminate these differences.

Table 2. Comparison between the different evaluation moments.

\begin{tabular}{|c|c|c|c|c|c|}
\hline Group & Moment & $\begin{array}{c}\text { Number of } \\
\text { Repetitions } \\
\text { (Mean } \pm \text { SD) }\end{array}$ & $\begin{array}{c}\text { Control vs. } \\
\text { Placebo } \\
\text { ( } p \text { value) }\end{array}$ & $\begin{array}{l}\text { IPC vs. } \\
\text { Placebo } \\
\text { ( } p \text { value) }\end{array}$ & $\begin{array}{l}\text { IPC vs. } \\
\text { Control } \\
\text { ( } p \text { value) }\end{array}$ \\
\hline \multirow{3}{*}{$\begin{array}{c}\text { ULG } \\
(n=12)\end{array}$} & Control & $31.4 \pm 5.1$ & \multirow{3}{*}{1.00} & \multirow{3}{*}{0.002} & \multirow{3}{*}{0.002} \\
\hline & Placebo & $31.4 \pm 5.0$ & & & \\
\hline & IPC & $34.8 \pm 4.8$ & & & \\
\hline \multirow{3}{*}{$\begin{array}{c}\text { LLG } \\
(n=12)\end{array}$} & Control & $28.9 \pm 6.0$ & \multirow{3}{*}{0.047} & \multirow{3}{*}{0.016} & \multirow{3}{*}{0.002} \\
\hline & Placebo & $33.5 \pm 10.4$ & & & \\
\hline & $I P C$ & $40.5 \pm 15.7$ & & & \\
\hline
\end{tabular}

ULG = upper limb group, LLG = lower limb group, SD = standard deviation, IPC = ischemic preconditioning Level of significance in the comparison between two moments $(p<0.017)$ from the Wilcoxon test with the Bonferroni correction. 


\section{DISCUSSION}

The objective of the present study was to evaluate the influence of the IPC on the neuromuscular performance of the upper and lower limbs in trained individuals. Our data confirmed the hypothesis that strength resistance improves several hours after the application of cycles of ischemia and reperfusion in the limbs involved in exercise, in that both the ULG and the LLG had better maximum repetition test performance after IPC intervention. These results corroborate a recent study that evaluated the number of extensions in a knee extension exercise at $85 \%$ of the $1 \mathrm{RM}$, showing a positive effect of the IPC on neuromuscular performance. ${ }^{17}$

In this study, the IPC protocol was performed by means of three five-minute cycles of ischemia interspersed with five minutes of reperfusion, in addition to a four-hour interval between the IPC and the exercises. This procedure was defined based on an important systematic review and meta-analysis that included 19 studies and demonstrated that the IPC had a beneficial effect on aerobic and anaerobic exercise performance, concluding that the protocol for the application of the IPC, as well as the time between the IPC and the effort, are determining factors of the effectiveness of the procedure. ${ }^{3}$ In contrast to the findings of the aforementioned study, another systematic review concluded that the IPC did not significantly influence physical performance or the related physiological variables. However, among the studies analyzed in this review, a great variation in the types of exercise, the times when the tests were performed and the time intervals between the IPC and the exercise were observed. ${ }^{20}$

To verify the real influence of the IPC on neuromuscular performance, the protocol of the present study included a placebo procedure, where the cuff pressure was only $20 \mathrm{mmHg}$ and did not cause ischemia. Our results showed that there was no placebo effect, as in both the ULG and the LLG improved performance was only observed when the cuff pressure was sufficient to cause ischemia (220 $\mathrm{mmHg}$ ), that is, in the real IPC intervention. Remember that this was a double-blind study, as the participants did not know that the procedure at $20 \mathrm{mmHg}$ was a placebo and, during the tests, the evaluator did not know whether the participant was in the IPC, placebo or control moment. On the other hand, a previous study evaluated 13 trained individuals under the same IPC, placebo and control conditions and observed small benefits to performance in the knee extension test in both the IPC and placebo. However, as that was not a blind study, there could have been influence from both the participants and the evaluators. ${ }^{21}$

Our results showed that the IPC significantly improved performance in the maximum repetitions tests of both upper and lower limbs. In addition, when analyzing the percentages of performance improvement, we noted that the IPC significantly influenced the performance of the lower limbs, probably because, in this case, the cuff used in the lower limb IPC was larger than that used for the upper limbs, that is, the area subjected to ischemia seems to influence the effect of the IPC, as indicated in previous studies. ${ }^{3}$

Considering that the thigh region allows application of the IPC to an area larger than the arm, it is recommended that the IPC be applied to the thigh even when the physical requirement is for the upper limbs, since the remote effect of the IPC was previously evidenced by a study that evaluated the manual pressure strength resistance of physically active men after undergoing IPC in the lower limbs. They observed that the IPC had a remote effect delaying the development of fatigue and, consequently, prolonging the time to failure. ${ }^{22}$

Along the same lines, another study observed a remote IPC effect in the elbow flexion test, however, in this study the placebo intervention also influenced the increase in the number of maximum repetitions, probably because the interval between the IPC and the effort was only 8 minutes and the study was not double-blind. ${ }^{23}$

The time between the application of the IPC and performing the exercise is an item that also deserves attention, since it varies greatly in the studies conducted to date and, therefore, a gap still exists in this regard. One study reported positive effects of the IPC on sprint and countermovement jump performance and recovery time, both immediately and 24 hours after IPC application. ${ }^{24}$ In another study, differences were not observed in the 1RM test or the number of repetitions to failure with the IPC applied 40 minutes before the bench press exercise, but the skin temperature in the biceps and chest region was reduced..$^{25}$ In the methodology of the present study, there was a four-hour time interval between the IPC and the exercise and a positive influence of the IPC on the number of repetitions was observed both in the bench press and the leg press exercises, suggesting that the four-hour interval between the IPC and the effort may be a good choice.

Certainly, when it comes to competitive sports, improved performance is the most desirable IPC effect, however, this improvement in performance can occur without significant changes in the physiological variables, in lactate concentration for example. ${ }^{17}$ Therefore, more in-depth studies of the physical responses to IPC can contribute to broadening the understanding of the influence of this method on performance. However, we emphasize that performance is still the most important aspect.

\section{Limitations}

It was not possible to collect blood samples in this study, making direct analysis of the physiological variables impossible. In addition, the study did not use electromyography, which would have guaranteed greater accuracy in the assessment of neuromuscular performance. However, the methods used here were rigorously implemented, ensuring the reproducibility and reliability of the results presented.

\section{CONCLUSION}

Our data showed that the IPC had a positive influence on neuromuscular performance, suggesting that this method can be used as a strategy to improve competitive performance in modalities that demand strength resistance of the upper and lower limbs.

IPC seems more effective when applied to the thigh than to the arm, in that a larger area can be subjected to ischemia. In addition, our data suggest that a four-hour interval between the IPC and the effort is a good choice for improving neuromuscular performance.

All authors declare no potential conflict of interest related to this article

\footnotetext{
AUTHORS' CONTRIBUTIONS: Each author made significant individual contributions to this manuscript. VJS and CEOD: Recruiting the participants, performing the intervention procedures, administering the tests, data analysis and writing;VMCS:Writing, review and intellectual concept; DPM: Elaboration of the project, supervision of the intervention procedures and data collection, statistical analysis, writing, review and intellectual concept.
}

\section{REFERENCES}

1. Halley SL, Marshall P, Siegler JC. The effect of IPC on central and peripheral fatiguing mechanisms in humans following maximal single limb isokinetic exercise. Physiol Rep. 2019;7(8):e14063.

2. Crisafulli A, Tangianu F, Tocco F, Concu A, Mameli O, Mulliri G, et al. Ischemic preconditioning of the muscle improves maximal exercise performance but not maximal oxygen uptake in humans. J Appl Physiol (1985). 2011;111(2):530-6.

3. Salvador AF, De Aguiar RA, Lisboa FD, Pereira KL, Cruz RS, Caputo F. Ischemic Preconditioning and Exercise 
Performance: A Systematic Review and Meta-Analysis. Int J Sports Physiol Perform. 2016;1 1(1):4-14.

4. Murry CE, Jennings RB, Reimer KA. Preconditioning with ischemia: a delay of lethal cell injury in ischemic myocardium. Circulation. 1986;74(5):1124-36.

5. Succi JE, Gerola LR, Succi GM, Almeida RA, Novais LS, Rocha B. Ischemic preconditioning influence ventricular function in off-pump revascularization surgery. Arq Bras Cardiol. 2010;94(3):319-24, 39-44.

6. Opie LH. Reperfusion injury and its pharmacologic modification. Circulation. 1989;80(4):1049-62.

7. Libonati JR, Cox M, Incanno N, Melville SK, Musante FC, Glassberg HL, et al. Brief periods of occlusion and reperfusion increase skeletal muscle force output in humans. Cardiologia. 1998;43(12):1355-60.

8. de Groot PC, Thijssen DH, Sanchez M, Ellenkamp R, Hopman MT. Ischemic preconditioning improves maximal performance in humans. Eur J Appl Physiol. 2010;108(1):141-6.

9. Jean-St-Michel E, Manlhiot C, Li J, Tropak M, Michelsen MM, Schmidt MR, et al. Remote preconditioning improves maximal performance in highly trained athletes. Med Sci Sports Exerc. 2011;43(7):1280-6.

10. Bailey TG, Jones H, Gregson W, Atkinson G, Cable NT, Thijssen DH. Effect of ischemic preconditioning on lactate accumulation and running performance. Med Sci Sports Exerc. 2012;44(11):2084-9.

11. Foster GP, Giri PC, Rogers DM, Larson SR, Anholm JD. Ischemic preconditioning improves oxygen saturation and attenuates hypoxic pulmonary vasoconstriction at high altitude. High Alt Med Biol. 2014;15(2):155-61

12. Tocco F, Marongiu E, Ghiani G, Sanna I, Palazzolo G, Olla S, et al. Muscle ischemic preconditioning does not improve performance during self-paced exercise. Int J Sports Med. 2015;36(1):9-15.

13. Slysz JT, Burr JF. Impact of 8 weeks of repeated ischemic preconditioning on running performance. Biomed Res Int. 2019;119(6):1431-7.

14. Kaur G, Binger M, Evans C, Trachte T, Van Guilder GP. No influence of ischemic preconditioning on running economy. Eur J Appl Physiol. 2017;117(2):225-35.

15. Paixao RC, da Mota GR, Marocolo M. Acute effect of ischemic preconditioning is detrimental to anaerobic performance in cyclists. Int J Sports Med. 2014;35(11):912-5.

16. Williams N, Russell M, Cook CJ, Kilduff LP. Effect of Ischemic Preconditioning on Maximal Swimming Performance. J Strength Cond Res. 2021;35(1):221-6.

17. Carvalho L, Barroso R. Ischemic Preconditioning Improves Strength Endurance Performance. J Strength Cond Res. 2019;33(12):3332-7.

18. Baechle TR, Earle RW. Essentials of strength training and conditioning. Champaign, Illinois: Human kinetics, 2008.

19. Rhea MR. Determining the magnitude of treatment effects in strength training research through the use of the effect size. J Strength Cond Res. 2004;18(4):918-20.

20. Marocolo M, da Mota GR, Simim MA, Appell Coriolano HJ. Myths and Facts About the Effects of Ischemic Preconditioning on Performance. Int J Sports Med. 2016;37(2):87-96.

21. Marocolo M, Willardson JM, Marocolo IC, da Mota GR, Simao R, Maior AS. Ischemic Preconditioning and Placebo Intervention Improves Resistance Exercise Performance. J Strength Cond Res. 2016;30(5):1462-9.

22. Barbosa TC, Machado AC, Braz ID, Fernandes IA, Vianna LC, Nobrega AC, et al. Remote ischemic preconditioning delays fatigue development during handgrip exercise. Scand J Med Sci Sports. 2015;25(3):356-64.

23. Marocolo M, Marocolo IC, da Mota GR, Simao R, Maior AS, Coriolano HJ. Beneficial Effects of Ischemic Preconditioning in Resistance Exercise Fade Over Time. Int J Sports Med. 2016;37(10):819-24.

24. Beaven CM, Cook CJ, Kilduff L, Drawer S, Gill N. Intermittent lower-limb occlusion enhances recovery after strenuous exercise. Appl Physiol Nutr Metab. 2012;37(6):1132-9.

25. Valenzuela PL, Martín-Candilejo R, Sánchez-Martínez G, Bouzas Marins JC, de la Villa P, Sillero-Quintana M. Ischemic Preconditioning and Muscle Force Capabilities. J Strength Cond Res. 2019. 